\title{
İntramedüller Çivilerin Statik ve Dinamik Eğilme Özelliklerinin Deneysel ve Teorik Olarak İncelenmesi
}

\author{
Halim KOVACI ${ }^{*}$ \\ * Atatürk Üniversitesi, Mühendislik Fakültesi, Makine Mühendisliği Bölümü, 25240, Erzurum
}

Geliş / Received: 17/08/2018, Kabul / Accepted: 29/03/2019

\begin{abstract}
Öz
Kemik iliği içerisine yerleştirilerek uzun kemiklerin tedavisinde kullanılan intramedüller çivilerden en büyük beklenti kemik iyileşmesi süresince hasara uğramamaları ve yeterli yük dağılımına olanak sağlamalarıdır. Ticari olarak farklı pek çok türde intramedüller çivi olmakla birlikte bu çiviler içerisinde en çok kullanılan türlerden biri silindirik kesitli içi boş olan türleridir. Ayrıca, intramedüller çivilerin en kötü koşullarda çalışmasını referans alan birçok uluslararası biyomekanik test standardında statik ve dinamik eğilme yükleri dikkate alınmaktadır. Ancak, içi boş şekilde üretilen intramedüller çivilerin, kesit kalınlığının değişimi sebebi ile bu yükler altında özelliklerinin ne yönde değişeceği bilinmemektedir. Bu sebeple, bu çalışmada, intramedüller çivilerde kesit etkisinin intramedüller çivilerinin statik ve yorulma dayanımları üzerindeki etkileri incelenmiştir. Bu amaçla, Grade 23 Ti6Al4V ELI malzemeden imal edilen 6.2, 6.7 ve $7.2 \mathrm{~mm}$ kesit kalınlığına sahip içi boş geometrideki intramedüller çiviler statik dört noktadan eğme ve yorulma testlerine tabii tutulmuşlar. Testler sonrasında, intramedüller çivilerde kesit kalınlığı arttıkça hem statik hem de yorulma dayanımlarının arttığı belirlenmiştir. Bununla birlikte, statik dört noktadan eğilme deneyleri sonucunda elde edilen sonuçlar ile teorik olarak hesaplanan değerler kullanılarak; intramedüller çivilerin tasarımı aşamasında kullanılabilecek matematiksel bir model oluşturulabileceği belirlenmiştir. Ayrıca, intramedüller çivilerde kesit kalınlığ 1 arttıkça yorulma dayanımının da arttığı ancak artan kesit kalınlığındaki artış oranı ile yorulma dayanımındaki artışın doğru orantılı olmadığı gözlemlenmiştir.
\end{abstract}

Anahtar Kelimeler: İntramedüller çivi, biyomekanik, eğilme, dört noktadan eğme, yorulma.

\section{Experimental and Theoretical Investigation of Static and Dynamic Bending Properties of Intramedullary Nails}

\begin{abstract}
The greatest expectation from intramedullary nails, which are used in the treatment of long bones by placing in the bone marrow, is that they cannot be damaged during bone healing and allow the adequate load distribution. There are many different kind of commercially available intramedullary nails and also, one of the mostly used types of this nails are hollow nails. Also, static and fatigue bending loads are taken into account in different international biomechanical test standards, which refers the worst-case working conditions. However, the intramedullary nails produced in hollow form are not known to change their properties under these loads due to the change in cross-sectional thickness. Therefore, the effects of cross-sectional thickness in intramedullary nails on their static and fatigue properties were investigated in this study. For this purpose, the hollow intramedullary nails manufactured from Grade 23 Ti6Al4V ELI with thicknesses of 6.2, 6.7 and $7.2 \mathrm{~mm}$ were subjected to static four-point bending and fatigue tests. After tests, it was observed that both static and fatigue strengths of nails improved with increasing cross-sectional thickness. Also, it was determined that a mathematical model to be used in the design process of nails can be established by using static four-point bending tests results and theoretical results. Additionally, it was observed that there wasn't a direct proportion between increasing cross-sectional thickness and increase rate of fatigue strength although fatigue properties of intramedullary nails improved when its cross-sectional thickness increased.
\end{abstract}

Keywords: Intramedullary nail, biomechanics, bending, four-point bending, fatigue.

\section{Giriş}

İskelet sistemi ve bu sistemin temel yapıtaşları olan kemikler kaza ve yaralanma gibi sebeplerle sıklıkla hasara uğrayarak ve/veya kırılarak işlevlerini ya kısmen ya da tamamen kaybetmektedirler. İnsanları günlük aktivitelerini sürdürebilmeleri için, kemikte düzensizlik veya sürekliliğin bozulması olarak tanımlanan kırıkların tedavi edilmesi 
gerekmektedir. Kemiklerin tedavisi için, kırığın hangi kemikte olduğu, konumu ve tipine göre; spinal implant, kemik plağ vidalar, kablo, disk protezi, eksternal fiksatör, intramedüller çivi vb. pek çok implant veya protez tek başına veya birlikte kullanılmaktadır. Bu yöntemler genel olarak; eksternal ve internal fiksasyon yöntemleri olarak iki gruba ayrilabilir. İnternal fiksasyon yöntemleri içerisinde intramedüller çiviler, uzun kemiklerin tedavisinde siklikla kullanılmaktadır (Perren, 2002). İntramedüller çiviler, silindirik geometriye sahip olan, içi boş veya dolu olarak imal edilebilen ve belirli bir uzunluğa sahip olan implantlar olarak tanımlanmaktadırlar. İntramedüller çiviler kemik iliği içerisine yerleştirilip, kemiklerin proksimal ve distal kısımlarında kilit vidaları (locking screw) ile bağlanarak; fragmanların (kırık kemikleri) birbirine göre uygun dizilimlerini sağlarlar (Eveleigh, 1995).

İntramedüller çiviler için en önemli özellikler; üretildikleri malzemeler ve tasarımlarıdır. İntramedüller çiviler kullanım alanlarına göre genellikle titanyum ve alaşımlarından ve/veya paslanmaz çelik malzemelerden üretilmektedirler. Uygun bir çivi tasarımında, intramedüller çivinin kemik geometrisine uygun olması ve yerleştirildiği kemik iliğine uygun bir şekilde oturması gerekmektedir. Bununla birlikte, titanyum ve alaşımları kırıkların fiksasyonu için yeterli stabilite sağlamalarına karşın, implant tasarımlarındaki farklılıklar ve malzeme özelliklerinden dolayı gereğinden daha rijit davranış gösterebilirler ve bu durum da çoğu kırık tedavisinde istenmeyen ve tedavi sürecini olumsuz yönde etkileyen bir sonuç oluşturmaktadır. Kemik iyileşme süresinin sağlıklı ve etkin bir şekilde gerçekleşmesi için implant ve kemikten oluşan yapıda, gelen yüklerin optimum seviyede paylaşılması ve kemiğin bir miktar mikro hareketliliğe maruz kalması gerekmektedir (Sha et al., 2009; Utvåg \& Reikerås, 1998; Wolff, 1986). İntramedüller çivi ve kemikten oluşan bir yapıda eğer intramedüller çivinin rijitliği kemiğe oranla çok yüksek ise kemik-implant yapısına gelen yükün çok büyük bir kısmı çivi tarafından taşınacak (gerilme kalkan etkisi/stress-shielding effect) ve bunun sonucunda da kemik iyileşme süresi uzayacak ve hatta kemik tekrar kırılma tehlikesi geçirebilecektir (Cheung, Zalzal, Bhandari, Spelt, \& Papini, 2004).

İntramedüller çivilerin farklı malzemelerden üretilmeleri durumundaki davranışları ve tasarım özellikleri literatürde farklı birçok çalışmada deneysel ve teorik olarak incelenmiştir (Bougherara et al., 2009; Kraemer et al., 2016; Letechipia, Alessi, Rodríguez, \& Asbun, 2014; Mehboob \& Chang, 2018; Montanini \& Filardi, 2010; Nourisa \& Rouhi, 2016; Samiezadeh, Avval, Fawaz, \& Bougherara, 2014; Shih, Hsu, \& Hsu, 2012; Wanzl, Foehr, Schreiber, Burgkart, \& Lenich, 2016). Bu çalışmalar genellikle intramedüller çivilerin kompozit malzemelerden üretilmesi veya tasarımlarının değiştirilerek elastik özellik gösterecek şekilde tasarlanması üzerine odaklanmışlardır. İntramedüller çivilerin kompozit malzemelerden üretilmesi konusu halen üzerinde pek çok klinik ve deneysel çalışma yapılan bir alandır. Ayrıca, biyouyumluluk özelliklerine sahip kompozit intramedüller çivilerin maliyetleri yüksek olabilmektedir. $\mathrm{Bu}$ nedenle, metalik intramedüller çiviler halen ticari olarak kullanılan ürün grubunu oluşturmaktadır. Bunlarla birlikte, metalik intramedüller çivilerde gerilme kalkan etkisini ortadan kaldırmak (rijitliği azaltmak) için en çok kullanılan tasarım metotları; çivilerin ince kesitli veya içi boş geometride üretilmesidir. $\mathrm{Bu}$ metotlar arasında ise çivilerin içi boş üretilmesi en çok uygulanan tasarım metodudur. Ayrıca, intramedüller çivilerin biyomekanik performansını klinik kullanımdan önce en kötü durumu (worst-case condition) dikkate alarak belirleyen standart testler arasinda en önemlilerinden biri çivilerin statik ve dinamik yükler altında eğilme testleridir (International, 2016; Pazos, 2015). Ancak, içi boş çivilerde kesit kalınlığının çivilerin statik ve dinamik yükler altında eğilme özelliklerini ne şekilde 
değiştireceği literatürde detaylı bir şekilde ele alınmamıştır.

$\mathrm{Bu}$ sebeplerle, bu çalışmada intramedüller çivilerde kesit özelliklerinin, çivilerin statik ve yorulma özelliklerine etkisinin belirlenmesi amaçlanmıştır. Bu amaçla, Grade 23 Ti6Al4V ELI malzemeden imal edilen 6.2, 6.7 ve $7.2 \mathrm{~mm}$ kesit kalınlığına sahip içi boş geometrideki intramedüller çiviler statik dört noktadan eğilme/eğme ve yorulma testlerine tabii tutulmuşlardır. Testler sonrasında ise, elde edilen deneysel sonuçlara göre hem intramedüller çiviler kendi arasında kıyaslanmış hem de teorik olarak hesaplanan sonuçlar ile karşılaştırılmıştır. Bunlarla birlikte, intramedüller çivilerde yorulma olayı ve hasar oluşum mekanizması da incelenmiştir.

\section{Materyal ve Metot}

İntramedüller çivilerde eğilme özelliklerinin incelenmesi amacı ile gerçekleştirilen bu çalışmada, farklı geometrik özelliklere sahip ve vücudun farklı bölgelerinde kullanılan üç farklı intramedüller çivi kullanılmıştır. Testlerde kullanılan intramedüller çiviler, Grade 23 Ti6Al4V ELI $\left(\sigma_{y}=918 M P a\right.$ ve $E=110 \mathrm{GPa}$ ) malzemeden üretilmiş olup; bu çiviler Şekil 1'de gösterilmiş ve ilgili geometrik özellikler Tablo 1'de verilmiştir.

İntramedüller çivilerde eğilme testleri statik ve dinamik (yorulma) olmak üzere iki farklı yükleme durumu için gerçekleştirilmiştir. ASTM F1264 (International, 2016)'e göre statik eğme testleri (dört noktadan eğme) için intramedüller çiviler, alt destek tablasina sırasıyla yerleştirilmiş ve üstten 2 noktadan kuvvet uygulayan aparat yardımı ile yüke maruz bırakılmıştır. Üst aparatta 2 kuvvet uygulama noktası arasındaki mesafe $114 \mathrm{~mm}$ olacak şekilde numuneler boyutları dikkate alınarak test standardına uygun olarak yerleştirilmiştir. Testin gerçekleştirilmesinde numunelerin yerleştirilme mesafe değerleri Tablo 2' de verilmiştir. İşlem hızı 5 $\mathrm{mm} /$ dak.olarak seçilmiş ve kuvvet-yer değiştirme (deplasman) eğrisi elde edilmiştir.

Yorulma testleri, statik eğme deneyleri ile aynı test planı ile ASTM F1264'e göre gerçekleştirilmiştir. Yorulma testleri, Instron 8872 servo hidrolik yorulma cihazı kullanılarak $5 \mathrm{~Hz}$ frekansta, kuru ortam havasında ve oda sicaklığında $\left(\sim 21^{\circ} \mathrm{C}\right)$ gerçekleştirilmiştir. Yorulma yük oranı $R=$ $F_{\min } / F_{\max }=M_{\min } / M_{\max }=0.1 \quad$ olup uygulanan bası yükünün formu sinüzoidaldir. Yorulma testleri intramedüller çivilerde hasar oluşuncaya kadar devam ettirilmiştir. Eğer hasar oluşmamış ise 5.000 .000 çevrim sonrası deney makinesi kapatılmıştır. Bütün deneyler için test konfigürasyonları Şekil 2'de gösterilmiştir. Eğme testlerinde kullanılan deney düzeneği ve numunelere ait örnek yerleşim düzeni Şekil 2-b' de gösterilmiştir.

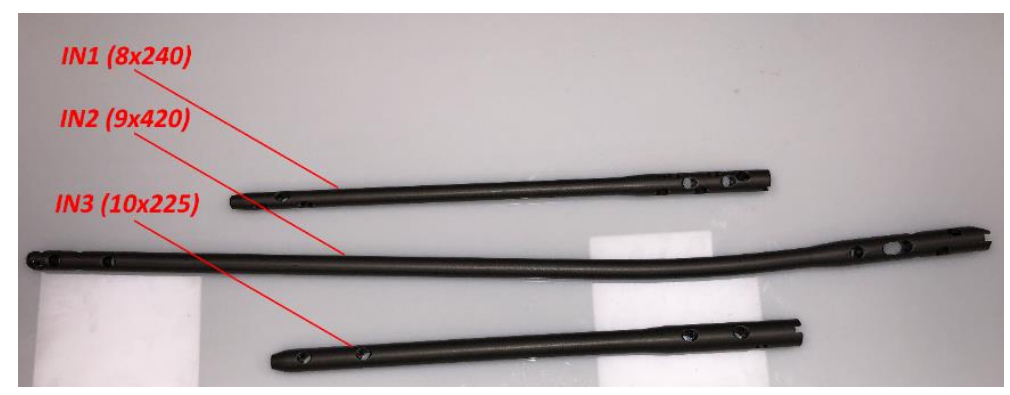

Şekil 1. Testlerde kullanılan intramedüller çiviler 
Tablo 1. Testlerde kullanılan intramedüller çivilerin geometrik özellikleri

\begin{tabular}{cccccc}
\hline $\begin{array}{c}\text { Intramedüller } \\
\text { Çivi Kodu }\end{array}$ & Kullanım & $\begin{array}{c}\text { Uzunluk } \\
\text { [mm] }\end{array}$ & $\begin{array}{c}\text { D (iç çap) } \\
\text { [mm] }\end{array}$ & $\begin{array}{c}\boldsymbol{d} \text { (iç çap) } \\
\text { [mm] }\end{array}$ & $\begin{array}{c}\boldsymbol{t}=\boldsymbol{D}-\boldsymbol{d} \\
{[\mathbf{m m}]}\end{array}$ \\
\hline IN1 & Humerus & 240 & 8 & 1.8 & 6.2 \\
IN2 & Tibia & 420 & 9 & 2.3 & 6.7 \\
IN3 & Artrodez/Tibia & 225 & 10 & 2.8 & 7.2 \\
\hline
\end{tabular}

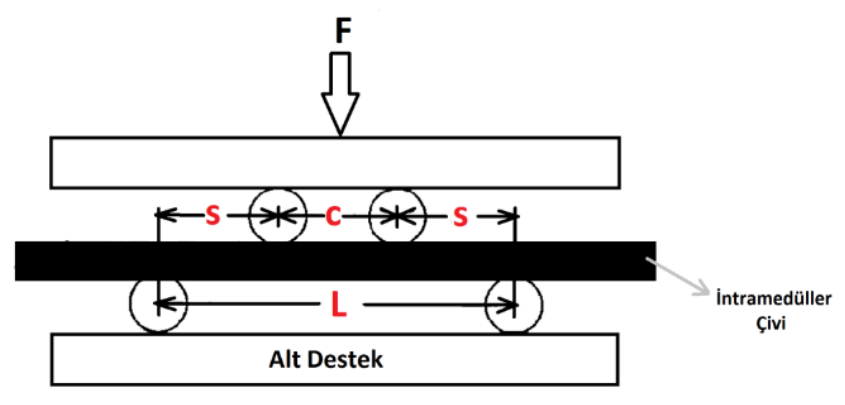

(a)

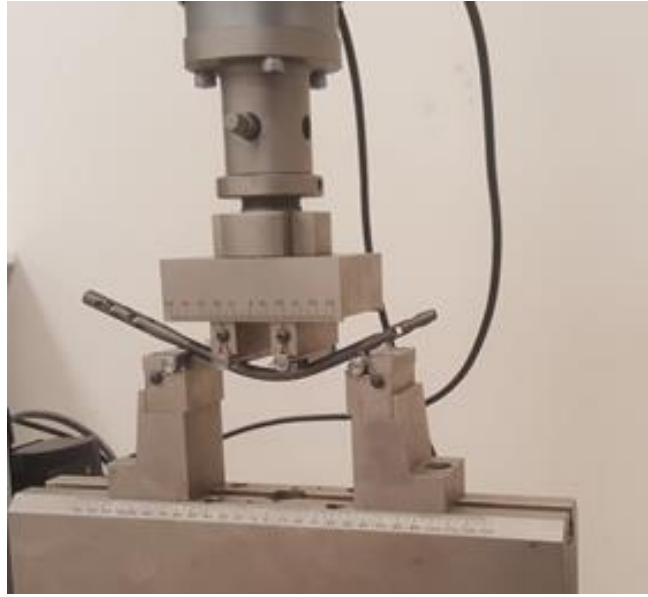

(b)

Şekil 2. Dört noktadan eğme deney düzeneği: (a) şematik gösterim (International, 2016) ve

(b) statik eğilme ve yorulma testleri esnasında alınan örnek görüntü

Tablo 2. İntramedüller çivilerin deney düzeneği üzerindeki konumları.

\begin{tabular}{lc}
\hline \multicolumn{1}{c}{ Parametre } & $\begin{array}{c}\text { Dĕger } \\
{[\mathbf{m m}]}\end{array}$ \\
\hline Alt destekler arası mesafe (L) & $\mathbf{1 1 4}$ \\
Alt ve üst destekler arası mesafe $(s)$ & $\mathbf{3 8}$ \\
Üst destekler arast mesafe (c) & $\mathbf{3 8}$ \\
\hline
\end{tabular}

\section{Bulgular ve Tartışma}

\subsection{Statik Dört Noktadan Ĕğme Deney Sonuçları}

Farklı kesit özelliklerine sahip intramedüller çivilere uygulanan dört noktadan eğme testlerinden elde edilen test sonuçlarına ait örnek kuvvet-deplasman grafiği Şekil 3'te gösterilmiştir. Burada, farklı çaplara sahip intramedüller çiviler için deformasyon davranışı benzer olduğundan (elastik ve plastik deformasyon ve deformasyon uzaması vb.); tek bir çivi için örnek grafik verilmiştir. İntramedüller çivilerde eğme testi gerçekleştirilirken, testler genellikle çivilerin hasarını beklenmeksizin maksimum kuvvet değeri belirleninceye kadar sürdürülmektedir. Şekil 3'ten görüleceği üzere; intramedüller çivi, test başladıktan sonra elastik şekil değişimi ve bunu takiben de plastik şekil değişimine uğramıştır. Bütün testlerde çiviler aynı deformasyon davranışını göstermiştir. Şekil 3 incelendiğinde, çivilerin hem elastik hem de plastik deformasyon boyunca oldukça fazla deplasman yaptıkları görülmektedir. Bunun sebebi, çivilerin titanyum alaşımından yapılmış olmasıdır. Bilindiği üzere, titanyum ve alaşımları sünek özellikte olduklarından, genellikle deformasyon esnasında yüzde uzama değerleri pek çok metalik malzemeden, özellikle biyomedikal uygulamalarda intramedüller çivi üretiminde kullanılan AISI 316L'den oldukça fazladır (Gyaneshwar et al., 2016).

Şekil 3'te ; $F_{y}$ : intramedüller çivilerin elastik şekil değişiminden plastik şekil değişimine geçtiği sınır değer olan akma kuvvetini, $F_{\text {max }}$ : intramedüller çivilerin plastik şekil değişimi esnasında dayanabileceği maksimum kuvvet değerini göstermektedir. İntramedüller çivilerin eğilme özelliklerinin belirlenmesi açısından $F_{y}$ ve $F_{\max }$ değerlerinin belirlenmesi gerekmektedir çünkü elde edilen bu değerler çivilerin hem kendi karakteristik özelliklerinin belirlenmesi hem de farklı tür ve 
$\begin{array}{ll}\text { özellikte intramedüller çivilerle } & \boldsymbol{M}_{\boldsymbol{y}}=\boldsymbol{F}_{\boldsymbol{y}} * \boldsymbol{s} / \mathbf{2} \\ \text { karşılaştırılmasına olanak sağlamaktadır. } & \end{array}$

Gerek mühendislik malzemelerinin genelinde gerekse implant uygulamalarında; ürünün performansinı etkileyen en önemli parametrelerden biri, akma dayanımıdır. Bilindiği üzere, akma dayanımı, malzemenin/ürünün/implantın elastik şekil değişiminden plastik (kalıcı) şekil değişimine geçtiği sınır yük değeri olarak tanımlanmaktadır. İntramedüller çivilerde de, implantların elastik sınırlar içerisinde çalışması gerektiği prensibi ile akma kuvvetleri $\left(\boldsymbol{F}_{\boldsymbol{y}}\right)$ referans alınmaktadır. Bununla birlikte, ASTM F1264-16 standardına göre intramedüller çivilerde, test edilen her çivinin geometrik özellikleri (boy, çap, kalınlık vb.) farklılık göstermekte ve bu sebeple de Şekil 2-a'da gösterilen yerleşim mesafeleri de farklı olmaktadır. Bu sebeple intramedüller çivi testlerinde, implantların plastik deformasyona geçiş sınırını belirleyen akma kuvvetlerinin $\left(\boldsymbol{F}_{\boldsymbol{y}}\right)$ yanı sira implantların test düzeneğindeki konumlarını da kapsayan akma momenti/akma anındaki moment $\left(\boldsymbol{M}_{\boldsymbol{y}}\right)$ değerleri de hesaplanmaktadır. Bu hesaplama, ASTM F1264-16 standardında da belirtildiği üzere Denklem $3.1 \quad$ kullanılarak yapılmaktadır. Burada $\boldsymbol{s}$, Şekil 2'de de gösterildiği üzere, alt ve üst destekler arasındaki mesafeyi göstermektedir.
Şekil 3'te gösterilen örnek grafiğe benzer şekilde, bütün intramedüller çiviler için kuvvet-deplasman grafikleri elde edilmiş ve bu grafiklerden belirlenen $F_{y}$ ve $F_{\text {max }}$ değerleri ve Tablo 1'de verilen uzunluklar dikkate alınarak intramedüller çivilerin ASTM F1264-16 standardında (International, 2016) belirtilen $\boldsymbol{M}_{\boldsymbol{y}}$ değerleri hesaplanmıştır. Hesaplanan değerler Tablo 3'te verilmiştir. Tablo 3 incelendiğinde, intramedüller çivilerde kesit kalınlığı (t) değeri arttıkça, beklendiği üzere; akma kuvvetinin değeri, maksimum kuvvet ve akma momenti değerleri de artış göstermiştir. En büyük kuvvet ve moment değerleri, en büyük kesit kalınlığına sahip olan IN3 kodlu çividen elde edilmiştir.

Bununla birlikte, intramedüller çivilerde bir diğer önemli parametre, çivinin rijitliğidir. İntramedüller çivilerde rijitlik, belirli bir yer değiştirme/deplasman miktarına karşılık gelen kuvvetin oranı olarak $(\boldsymbol{F} / \boldsymbol{y})$ olarak tanımlanmaktadır ve elastik şekil değişimi bölgesinin yani lineer kısmın eğiminin bulunması ile elde edilmektedir. Tablo 3'ten görüldüğü üzere, artan kesit kalınlığı ile rijitlik $(\boldsymbol{F} / \boldsymbol{y})$ değerleri de artış göstermiştir. $\mathrm{Bu}$ artış mekanik açıdan beklendik bir sonuç olmasına karşın gerek biyomekanik gerekse klinik açıdan önem taşımaktadır.

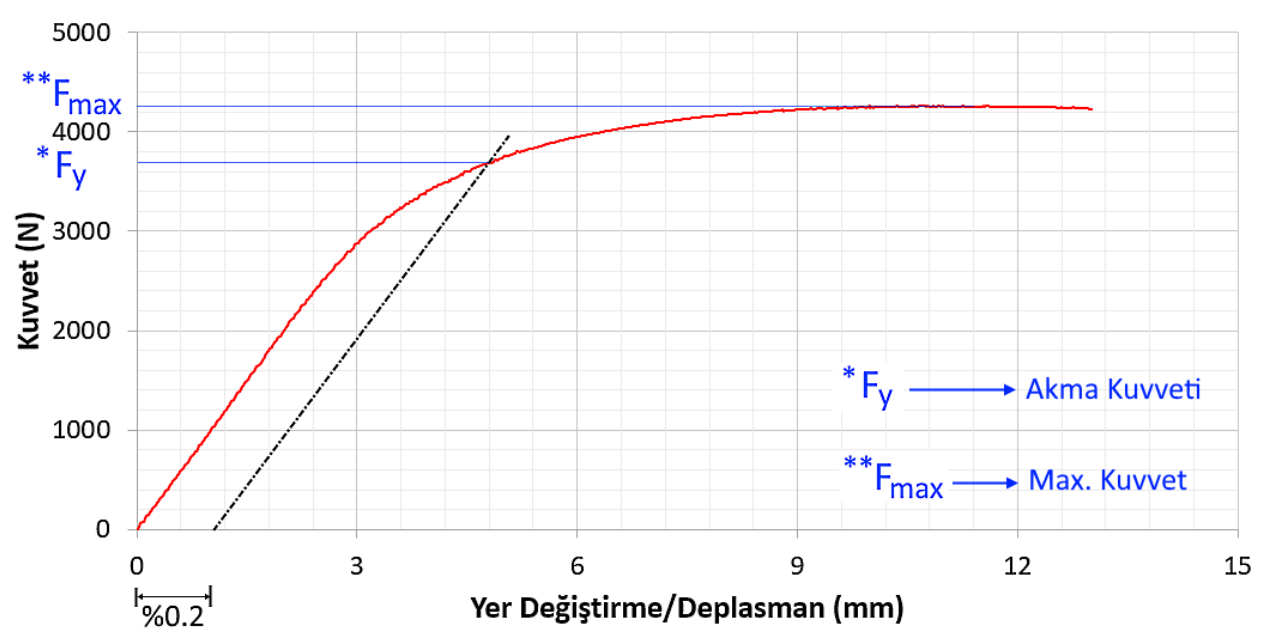

Şekil 3. Dört noktadan eğme deneylerinden elde edilen örnek kuvvet-yer değiştirme grafiğgi. 
Tablo 3. İntramedüller çiviler için ASTM F1264-16 (International, 2016) standardına göre belirlenen ve hesaplanan özellikler

\begin{tabular}{cccccc}
\hline $\begin{array}{c}\text { Test } \\
\text { Grubu }\end{array}$ & $\begin{array}{c}\boldsymbol{t}=\boldsymbol{D}-\boldsymbol{d} \\
(\mathbf{m m}) \\
\text { Çaplar Farkı }\end{array}$ & $\begin{array}{c}\boldsymbol{F}_{\boldsymbol{y}}(\mathbf{N}) \\
\text { Akma Kuvvetinin } \\
\text { Değeri }\end{array}$ & $\begin{array}{c}\boldsymbol{F} / \boldsymbol{y}(\mathbf{N} / \mathbf{m m}) \\
\text { Lineer Kismın } \\
\text { Eğimi }\end{array}$ & $\begin{array}{c}\boldsymbol{F}_{\text {max }}(\mathbf{N}) \\
\text { Maksimum } \\
\text { Kuvvet }\end{array}$ & $\begin{array}{c}\boldsymbol{M}_{\boldsymbol{y}}-(\mathbf{N} . \mathbf{m m}) \\
\text { Akma Anındaki } \\
\text { Ortalama } \\
\text { Moment }\end{array}$ \\
\hline $\boldsymbol{I N 1}$ & 6.2 & 2590 & 670 & 3850 & 49210 \\
\hline $\boldsymbol{I N 2}$ & 6.7 & 4000 & 1300 & 5950 & 75950 \\
\hline $\boldsymbol{I N 3}$ & 7.2 & 6395 & 1610 & 8100 & 101550 \\
\hline
\end{tabular}

Kemik iliğinin içerisine yerleştirilerek kırıkların tedavisinde kullanılan intramedüller çiviler, kırık iyileşme sürecini ve süresini direkt olarak etkilemektedirler. Kırık tipine göre, intramedüller çivilerin ya olabildiğince rijit ya da belirli bir esnekliğe/hareket kabiliyetine sahip olması istenebilmektedir.

Kırıkların tedavisinde, iyileşme süreci kişiden kişiye farklılık göstermektedir. Bununla birlikte, iyileşme süreci genel olarak iki aşamaya ayrılabilir: bunlardan birincisi kemiklerin uç uca birleşmeye başlamasına olanak sağlayan kallus oluşumu ve ikincisi ise kemiğin süreç içerisinde iyileşme aşamalarıdır. Kallus oluşumu aşamasında, kallusun bozulmaması için kemik ve implanttan oluşan yapının şekil değiştirmez/rijit özellikte olması istenmektedir. Ancak, kallus oluşumundan sonraki süreçte ise, iyileşme sürecinin olumlu yönde etkilenmesi için, kemik ve implanttan oluşan yapının tamamen hareketsiz değil, bir miktar hareketli (micro motion) olması istenebilmektedir (Duckworth \& Blundell, 2010). Bu bakımdan, her tür tedavi için kalın kesitli çivilerin kullanılması doğru olmayacaktır. Kırığın konumuna ve türüne göre en uygun kesit kalınlığının seçilmesi gerekmektedir.

Elde edilen sonuçlara göre ise; fiksasyonun tamamen rijit seçilmesi gerektiği durumlarda kesit kalınlığı büyük çiviler (IN3 gibi) seçilebilir ancak elastikiyet istenen durumlarda ise daha ince kesitli çiviler (IN1 gibi) tercih edilebilir.

\subsection{Teorik Hesaplamalar Karşılaştırma}

Bu çalışmada ele alınan intramedüller çiviler içi boş kesite sahiptirler ve Şekil 2'den de görüleceği üzere, eğilme yüklerine maruz kalmaktadırlar. $\mathrm{Bu}$ sebeple, intramedüller çiviler, içi boş ve basit eğilmeye maruz birer eleman olarak ele alınabilirler. Buradan hareketle, çivilerin dış ve iç çapları ve malzeme özellikleri bilindiği için; alan atalet momentleri belirlenerek, akma momentleri teorik olarak hesaplanabilir. Bu hesaplamalar Denklem 3.2 ve Denklem 3.3 (Pazos, 2015; Timoshenko \& MacCullough, 1949) kullanılarak yapılmış ve elde edilen sonuçlar Tablo 4'te verilmiştir. Burada I; alan atalet momentini, $\boldsymbol{D}$ ve $\boldsymbol{d}$; sırasıyla çivilerin dış ve iç çaplarını, $\sigma_{\boldsymbol{y}}$; çivi malzemesinin akma gerilmesi değerini ve $\boldsymbol{M}_{\boldsymbol{y}}$; akma momentini göstermektedir.

$$
\begin{aligned}
& I=\frac{\pi *\left(D^{4}-d^{4}\right)}{64} \\
& M_{y}=\frac{2 * \sigma_{y} * I}{D}
\end{aligned}
$$

(Denklem 3.2)

(Denklem 3.3)

Deneysel olarak belirlenen ve teorik olarak hesaplanan akma momenti değerleri $\left(\boldsymbol{M}_{\boldsymbol{y}}\right)$ Tablo 4'te verilmiştir. Buradan görüldüğü üzere, intramedüller çivilerde kesit kalınlığının artması ile hem deneysel hem de teorik akma momenti değerleri beklendiği üzere artış göstermiştir. Bununla birlikte; bir diğer dikkat çekici nokta, deneysel ve teorik olarak elde edilen değerler arasındaki farktır. Deneysel olarak elde edilen akma momenti değerleri her bir çivi için teorik sonuçlardan yüksektir ve bu değerler arasında IN1, IN2 ve IN3 çivileri için sırasıyla $\% 6.50, \% 7.80$ ve ve $\% 11.80$ 'lik farklar oluşmuştur. Elde edilen bu farklar, çok yüksek mertebelerde olmasa dahi; 
intramedüller çivilerin malzeme özellikleri ve test esnasındaki değişimler ile açıklanabilir. Teorik hesaplamalarda intramedüller çivi malzemesinin deneysel olarak elde edilen akma değeri kullanıldı ise de, bilindiği üzere, intamedüller çivi malzemesinde yer alan herhangi bir düzensizlik, dislokasyon yoğunluğunun malzeme içerisinde bölgesel olarak farklı olması veya malzeme yapısında bulunabilecek tekstür/ yönlenme farklılıkları, teorik sonuçlar ile deneysel sonuçlar arasında farklılık oluşmasına sebep olabilir (Pazos, 2015). Ayrıca, bu farklılığın oluşmasının bir diğer sebebi de, test esnasında intramedüller çivilerin konumları veya deney düzeneğine yerleşim şekilleridir. Test esnasında, intramedüller çivilerin çok düşük miktarda da olsa hareket etmiş olması ve/veya test düzeneğine çok küçük farklılıklar ile bağlanması da (farklı pozisyonlarda) böyle bir farklılığın oluşmasına sebep olabilir.

Deneysel ve teorik olarak hesaplanan akma momentleri arasındaki ilişki Şekil 4'te gösterilmiştir ve başka bir çalışmada da kullanılan matematiksel metot kullanılarak (Pazos, 2015), deneysel ve teorik değerler arasında matematiksel bir model kurulmuştur. Burada, belirlilik katsayısı değeri $R^{2}=$ 0.9778 olarak elde edilmiştir ve bu değer matematiksel modelin iyi olduğunu göstermektedir. $\mathrm{Bu}$ matematiksel modelin kullanılması, intramedüller çivi tasarımcilarına, deney yapılmaksızın sadece teorik hesaplamalar ile ön bilgi sağlayabilecek olması sebebi ile önem taşımaktadır. Örneğin; bu veya benzeri bir model ile bir intramedüller çivi tasarımında kullanılan malzemenin akma dayanımı ve kesit özelliklerinin bilinmesi ile teorik akma momenti belirlenip, deneysel sonuçların hangi değerlere sahip olabileceği tespit edilebilir. Bununla birlikte, intramedüller çivilerde tasarımlar (dış ve iç çap değerleri) değiştirilerek veya malzeme özellikleri değiştirilerek (farklı malzemelerin kullanılması halinde) yeni tasarımların deneysel davranışı hakkında ön bilgi sahibi olunabilir (Pazos, 2015).

Tablo 4. Akma anındaki moment için deneysel ve teorik değerler

\begin{tabular}{|c|c|c|c|c|c|c|c|}
\hline & $\begin{array}{l}\boldsymbol{D}(\boldsymbol{m m}) \\
\text { Diş Çap }\end{array}$ & $\begin{array}{l}d(m m) \\
\text { İç Çap }\end{array}$ & $\begin{array}{c}t=D-d \\
(\boldsymbol{m m}) \\
\text { Çaplar } \\
\text { Fark1 }\end{array}$ & $\begin{array}{c}I-\left(\mathbf{m m}^{4}\right) \\
\text { Atalet } \\
\text { Momenti }\end{array}$ & $\begin{array}{c}\text { Teorik } \\
M_{y}-(\text { N.mm }) \\
\text { Akma } \\
\text { Momenti }\end{array}$ & $\begin{array}{c}\text { Deneysel } \\
M_{y}-(\text { N.mm }) \\
\text { Akma Momenti }\end{array}$ & $\begin{array}{c}M_{y} \\
\text { Dĕgerleri } \\
\text { arasındaki } \\
\text { \% fark }\end{array}$ \\
\hline IN1 & 8 & 1.8 & 6.2 & 200.445 & 46002.12 & $49210 \pm 860$ & 6.50 \\
\hline IN2 & 9 & 2.3 & 6.7 & 320.526 & 65387.32 & $70950 \pm 650$ & 7.80 \\
\hline IN3 & 10 & 2.8 & 7.2 & 487.609 & 89525.08 & $101550 \pm 1050$ & 11.80 \\
\hline
\end{tabular}

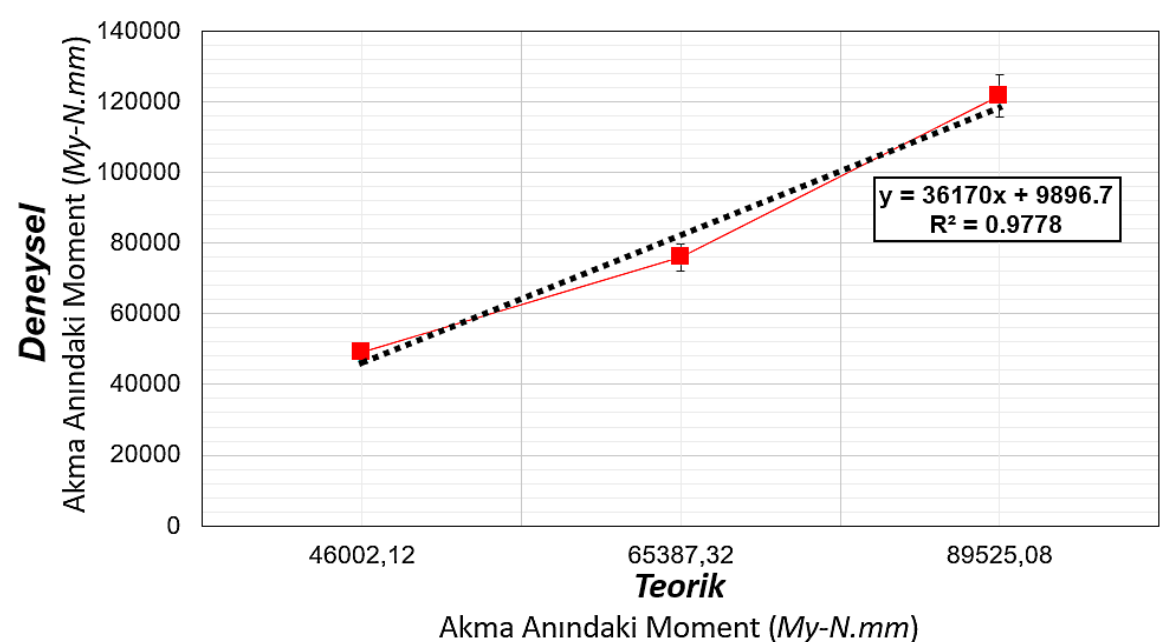

Şekil 4. Deneysel ve teorik akma anındaki moment değerleri arasındaki ilişki 


\subsection{Yorulma Deney Sonuçları}

İntramedüller çiviler için gerçekleştirilen yorulma deneyleri sonrasında elde edilen sonuçlar Tablo 5'te verilmiş ve bu sonuçlara göre çizilen maksimum eğilme kuvvetiçevrim sayısı grafiği de Şekil 5'te gösterilmiştir. Buradan görüleceği üzere, her bir intramedüller çivi için yorulma deneylerinde başlangıç yük değeri olarak statik dört noktadan eğilme deneylerinden elde edilen akma kuvveti değerleri referans alınmıştır. Yorulma yükleri, bu yükten itibaren kademeli olarak azaltılmış ve çivilerde 5.000.000 çevrim sayısı sonsuz ömür (yorulma limit değeri) olarak kabul edilerek deneyler gerçekleştirilmiştir. Yorulma deneyleri sonrasinda 5.000 .000 çevrim sonrasında IN1, IN2 ve IN3 çivileri için yorulma limit değerlerinin maksimum değerleri sirası ile $1500 \mathrm{~N}, 2700 \mathrm{~N}$ ve $4200 \mathrm{~N}$ olarak belirlenmiştir. Buradan anlaşılacağ1 üzere, çivilerde kesit kalınlığı arttıkça yorulma limit değerleri de artış göstermiştir ve en yüksek yorulma limit değeri IN3 çivisinden elde edilmiştir.

İntramedüller çivilerde gerçekleştirilen dört noktadan eğme ve yorulma deney sonuçları göstermiştir ki, intramedüller çivilerde kesit kalınlığ 1 arttıkça akma dayanımı ve yorulma limit değerleri de artmaktadır. Statik dört noktadan eğilme deneylerinden elde edilen sonuçlar incelendiğinde; deneysel sonuçların teorik olarak hesaplanan değerler ile uyum gösterdiği ve bu değerlerin matematiksel bir model ile tarif edilebileceği belirlenmiştir. $\mathrm{Bu}$ durum ise, deney yapılmadan önce kullanılacak matematiksel modellerin deneyler öncesinde araştırmacılara fikir verebileceği ve deney sayısının azaltılmasına da katkıda bulunabileceğini göstermiştir. Ancak bu durum intramedüller çivilerin yorulma dayanımlarının belirlenmesi için geçerli değildir.

Tablo 5. İntramedüller çiviler için yorulma (dinamik dört noktadan eğme) deney sonuçları

\begin{tabular}{|c|c|c|c|c|c|c|c|}
\hline & \multirow{2}{*}{$\begin{array}{l}\text { IN1 } \\
\text { Kuvvet }(\mathrm{N})\end{array}$} & \multicolumn{2}{|r|}{ IN2 } & \multicolumn{2}{|r|}{ IN3 } & \multirow[b]{2}{*}{$\begin{array}{c}\text { Çevrim } \\
\text { sayısı }\end{array}$} & \multirow[b]{2}{*}{ Gözlem } \\
\hline & & $\begin{array}{c}\text { Çevrim } \\
\text { sayısı }\end{array}$ & Kuvvet $(\mathbf{N})$ & $\begin{array}{c}\text { Çevrim } \\
\text { sayısı }\end{array}$ & Kuvvet (N) & & \\
\hline 1 & $-250 /-2500$ & 1 & $-400 /-4000$ & 1 & $-630 /-6300$ & 1 & Deformasyon \\
\hline 2 & $-225 /-2250$ & 82.193 & $-360 /-3600$ & 33.928 & $-600 /-6300$ & 30.655 & Kırılma \\
\hline 3 & $-180 /-1800$ & 133.557 & $-320 /-3200$ & 412.003 & $-525 /-5250$ & 336.254 & Kırılma \\
\hline 4 & $-175 /-1750$ & 832.556 & $-300 /-3000$ & 112.683 & $-450 /-4500$ & 1.225 .324 & Kırılma \\
\hline 5 & $-160 /-1600$ & 2.873 .481 & $-280 /-2800$ & 1.673 .145 & $-430 /-4300$ & 2.106 .841 & Kirllma \\
\hline 6 & $-160 /-1600$ & 2.394 .698 & $-280 /-2800$ & 2.130 .877 & $-430 /-4300$ & 3.312 .873 & Kırılma \\
\hline 7 & $-150 /-1500$ & 5.000 .000 & $-270 /-2700$ & 5.000 .000 & $-420 /-4200$ & 5.000 .000 & Hasar yok \\
\hline 8 & $-150 /-1500$ & 5.000 .000 & $-270 /-2700$ & 5.000 .000 & $-420 /-4200$ & 5.000 .000 & Hasar yok \\
\hline
\end{tabular}

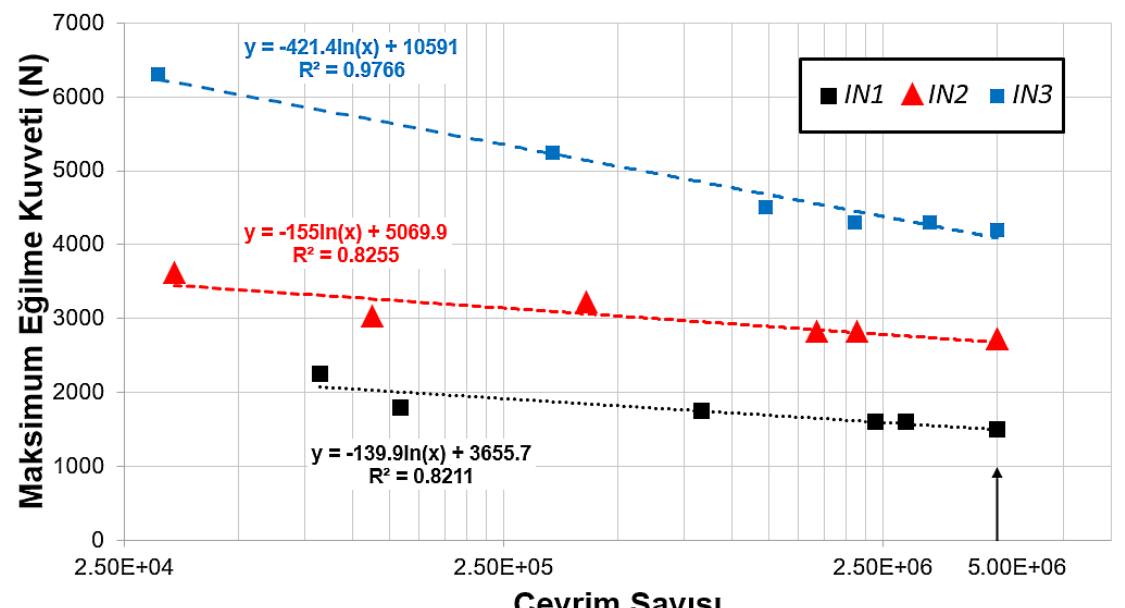

Şekil 5. Yorulma deneyleri sonucunda elde edilen maksimum eğilme kuvveti-çevrim sayısı grafiği 
İntramedüller çivilerin kesit kalınlığındaki değişime karşıllk statik dört noktadan eğilme ve yorulma deneyleri sonucunda belirlenen akma momenti ve yorulma limit değerlerinin değişimi Şekil 6'da gösterilmiştir. Kesit kalınlığı arttıkça intramedüller çivilerin hem akma momenti hem de yorulma limit değerlerinin artmıştır.

Elde edilen yorulma limit değerleri; IN1, IN2 ve IN3 intramedüller çivilerinin akma yükü ve/veya akma momenti değerlerinin sirasiyla $\% 60, \% 67.5$ ve \%66.6'sina denk gelmektedir. Buradan, kesit çapları ve dolayısı ile de artan akma kuvvetleri veya akma momentleri ile yorulma dayanımı arasında doğru orantılı bir artış eğilimi olmadığı anlaşılmaktadır. Çünkü Şekil 6'da gösterildiği üzere her bir intramedüller çivi kesit kalınlığı arasında 0.5 mm'lik bir artış olmasına rağmen IN1 ve IN2 intramedüller çivileri akma dayanımlarının sirasiyla $\% 60$ ve $\% 67.5$ 'ine denk gelirken bu oran IN3 çivisinin \% 66.6's1 oranındadır. Bu durum hem intramedüller çivilerin malzeme özellikleri hem de yorulma olayının istatistiksel değişkenliğinden dolayıdır.

Dört noktadan eğilme deney sonuçlarında da belirtildiği üzere; intramedüller çivilerin yapısında bulunan herhangi bir düzensizlik, dislokasyon yoğunluğunun malzeme içerisinde bölgesel farklılığı veya malzeme yapısında bulunabilecek tekstür/yönlenme farklı1ıkları yorulma değerlerini direkt olarak etkilemektedir. Bununla birlikte, yorulma olayı istatistiksel olarak değişken özelliktedir ve bu durum da kesit kalınlığı-akma dayanımı-yorulma dayanımı arasındaki artış eğilimini etkilemektedir. Bu sebeplerle, her ne kadar artan kesit kalınlığ 1 ve artan akma dayanımı ile yorulma limit değerleri artış göstermiş olsa dahi, bu değeler arasındaki artışlar arasında direkt olarak bir doğru orantı kurulamamaktadir.

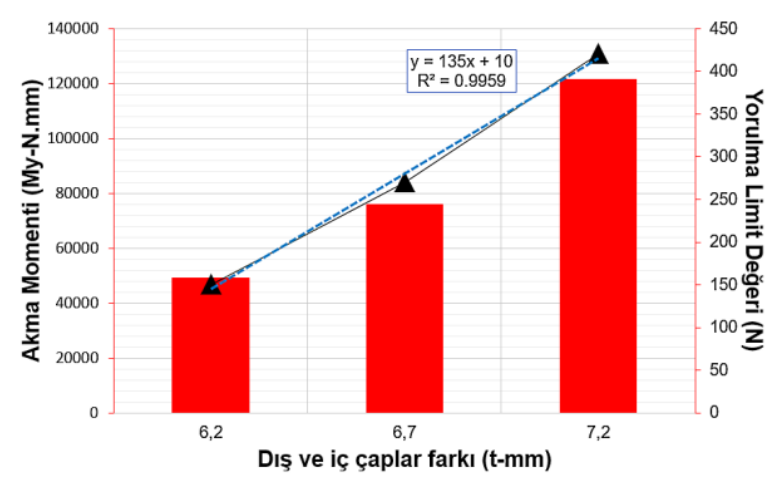

Şekil 6. Dış-iç çap farkları, akma momenti ve yorulma limit değerleri arasındaki ilişki.

Yorulma testleri sonrasında hasara uğrayan intramedüller çivilerin kırılma görüntüleri Şekil 7'de verilmiştir. Şekil 7-a'dan görüldüğü üzere intramedüller çivilerde yorulma testleri sonrasinda, uygulanan yorulma yüklerinin akma dayanımının altında olması sebebi ile çivilerin genel formu açısından herhangi bir kalıcı şekil değişimi veya eğilme olmaksızın kırılma hasarının gerçekleştiği görülmektedir. Bununla birlikte, çivi kesit alanına bakılmaksızın, kırılma hasar şekli bütün intramedüller çivilerde aynıdır ve kırılma hasarı intramedüller çivilerin orta kısımlarında gerçekleşmiştir.

Şekil 2-b'den de açıkça görüleceği üzere intramedüller çiviler, en fazla eğilme momentine maruz kaldıkları kısımlardan hasara uğramışlardır. Bununla birlikte, Şekil 7-b'de örnek kırılma hasar yüzeyi detaylı bir biçimde gösterilmiştir. Burada verilen detay resimleri incelendiğinde, intramedüller çivilerin kırılan kesitlerinin düzgün bir forma sahip olmadığı görülmektedir. Daha önce bahsedildiği üzere çivilerde genel şekil itibarı ile herhangi bir kalıcı deformasyon olmamasına ya da kırılma bölgeleri hariç şeklen bir bozulma olmamasına karşın çivilerin kırılma bölgeleri incelendiğinde; kırılma olayının, yorulma çatlağ $1 /$ hasarı başladıktan sonra kesitin uygulanan kuvvetleri taşıyamaması ve hasara uğraması şeklinde gerçekleştiği görülmektedir. Ayrıca, kırılma yüzeylerinin düz bir kırılma yüzey formuna sahip olmaması, kırılma karakterinin sünek kırılma şeklinde geliştiğini göstermektedir. Burada, yorulma çatlağının başlamasından sonra çiviler mikro plastik deformasyona uğramış ve akabinde ise bu 
plastik deformasyonun kesit boyunca devam etmesi ile kırılmışlardır. Testlerde kullanılan çiviler, Ti6AlV malzemeden yapılmış olması ve bu malzemenin de sünek karakterde olması bu bulguyu desteklemektedir.
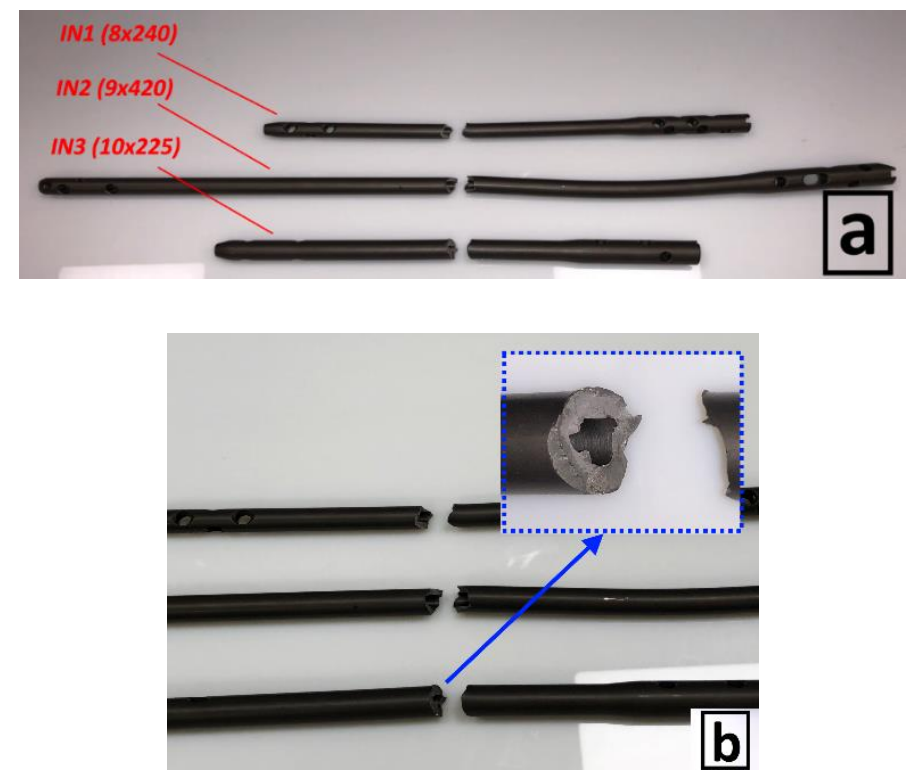

Şekil 7. Yorulma testleri sonrasında intramedüller çivilerin görüntüsü: (a) genel görünüm ve (b) detay görüntüleri.

\section{Sonuçlar}

İntramedüller çivilerde kesit etkisinin çivilerin eğilme davranışına etkilerinin teorik ve deneysel olarak incelendiği ve karşılaştırıldığı bu çalışmada; $6.2,6.7$ ve 7.2 $\mathrm{mm}$ kesit kalınlığına sahip içi boş geometrideki intramedüller çiviler statik dört noktadan eğme/eğilme ve yorulma testlerine tabi tutulmuş ve elde edilen sonuçlar aşağıda verilmiştir:

- İntramedüller çivilerde kesit kalınlığı arttıkça, çivilerin akma kuvveti ve akma momenti değerlerinin arttığ yüksek akma dayanımı ve yorulma dayanımı $7.2 \mathrm{~mm}$ kesit kalınlığına sahip çividen elde edilmiştir.

- Dört noktadan eğilme deneyleri sonucunda elde edilen akma momenti değerleri, teorik sonuçlar ile karşılaştırıldığında; teorik ve deneysel sonuçlar arasında maksimum \%11.8'lik bir fark oluştuğu ve bu farkın, intramedüller çivilerinin yapısal farklılıkları ve/veya testler esnasındaki kaynaklanabileceği belirlenmiştir.

- İntramedüller çivilerinin dört noktadan eğilme deneyleri sonrasında elde edilen ve teorik olarak hesaplanan akma momentleri arasında belirlilik katsayısı yüksek bir matematiksel model kurulabileceği belirlenmiş ve bu modelin intramedüller çivilerin tasarımı aşamasında veya deney sayısını azaltmak için kullanılabileceği belirlenmiştir.

- $\quad 6.2,6.7$ ve $7.2 \mathrm{~mm}$ kesit kalınlığına sahip intramedüller çiviler için yorulma dayanımlarının, bu çivilerin deneysel olarak belirlenen akma yüklerinin sirasıyla $\% 60$ ve $\% 67.5$ ve \%66.6'sına denk geldiği tespit edilmiştir.

Yorulma deneylerinde elde edilen sonuçlara bağlı olarak, intramedüller çivilerde artan kesit kalınlığı ve akma dayanımının yorulma dayanımını da aynı oranda artırmadığ1 gözlemlenmiş ve buna bağlı olarak da bu özellikler arasında matematiksel bir modelin direkt olarak kurulamayacağ1 belirlenmiştir.

\section{Teşekkür}

$\mathrm{Bu}$ çalışmada kullanılan intramedüller çivileri üreten ve sonuçların paylaşılmasına izin veren Atılgan Tıbbi Ürünler Sağlık Hizmetleri A.Ş. adına Sayın Alaettin Bilem'e teşekkür ederim. 


\section{Kaynaklar}

Bougherara, H., Zdero, R., Miric, M., Shah, S., Hardisty, M., Zalzal, P., \& Schemitsch, E. 2009. The biomechanics of the T2 femoral nailing system: a comparison of synthetic femurs with finite element analysis. Proceedings of the Institution of Mechanical Engineers, Part H: Journal of Engineering in Medicine, 223(3), 303-314.

Cheung, G., Zalzal, P., Bhandari, M., Spelt, J., \& Papini, M. 2004. Finite element analysis of a femoral retrograde intramedullary nail subject to gait loading. Medical engineering \& physics, 26(2), 93-108.

Duckworth, T., \& Blundell, C. M. 2010. Lecture Notes: Orthopaedics and Fractures (Vol. 12): John Wiley \& Sons.

Eveleigh, R. 1995. A review of biomechanical studies of intramedullary nails. Medical engineering \& physics, 17(5), 323-331.

Gyaneshwar, T., Nitesh, R., Sagar, T., Pranav, K., Rustagi, N. 2016. Treatment of pediatric femoral shaft fractures by stainless steel and titanium elastic nail system: A randomized comparative trial. Chinese Journal of Traumatology, 19(4), 213-216.

International, A. 2016. ASTM F1264 - 16e1 Standard Specification and Test Methods for Intramedullary Fixation Devices. In: ASTM International.

Kraemer, M., Schilling, M., Eifler, R., Hering, B., Reifenrath, J., Besdo, S., . . W Weizbauer, A. 2016. Corrosion behavior, biocompatibility and biomechanical stability of a prototype magnesium-based biodegradable intramedullary nailing system. Materials Science and Engineering: C, 59, 129-135.

Letechipia, J., Alessi, A., Rodríguez, G., \& Asbun, J. 2014. Design and preliminary testing of an active intramedullary nail. Revista de Investigacion Clinica, 66(S1), 7078.

Mehboob, A., \& Chang, S.-H. 2018. Biomechanical simulation of healing process of fractured femoral shaft applied by composite intramedullary nails according to fracture configuration. Composite Structures, $185,81-93$.

Montanini, R., \& Filardi, V. 2010. In vitro biomechanical evaluation of antegrade femoral nailing at early and late postoperative stages. Medical engineering \& physics, 32(8), 889-897.

Nourisa, J., \& Rouhi, G. 2016. Biomechanical evaluation of intramedullary nail and bone plate for the fixation of distal metaphyseal fractures. Journal of the Mechanical Behavior of Biomedical Materials, 56, 34-44.

Pazos, L. 2015. Bending Performance Prediction of Intramedullary Nails. Paper presented at the VI Latin American Congress on Biomedical Engineering CLAIB 2014, Paraná, Argentina 29, 30 \& 31 October 2014.

Perren, S. M. 2002. Evolution of the internal fixation of long bone fractures: the scientific basis of biological internal fixation: choosing a new balance between stability and biology. The Journal of bone and joint surgery. British volume, 84(8), 1093-1110.

Samiezadeh, S., Avval, P. T., Fawaz, Z., \& Bougherara, H. 2014. Biomechanical assessment of composite versus metallic intramedullary nailing system in femoral shaft fractures: A finite element study. Clinical Biomechanics, 29(7), 803-810.

Sha, M., Guo, Z., Fu, J., Li, J., Fan Yuan, C., Shi, L., \& Jun Li, S. 2009. The effects of nail rigidity on fracture healing in rats with osteoporosis. Acta orthopaedica, 80(1), 135138.

Shih, K.-S., Hsu, C.-C., \& Hsu, T.-P. 2012. A biomechanical investigation of the effects of static fixation and dynamization after interlocking femoral nailing: a finite element study. Journal of Trauma and Acute Care Surgery, 72(2), E46-E53.

Timoshenko, S., \& MacCullough, G. H. 1949. Elements of strength of materials. 
Utvåg, S., \& Reikerås, O. 1998. Effects of nail testing to evaluate the cut-through resistance rigidity on fracture healing. Archives of of intramedullary nails for the proximal orthopaedic and trauma surgery, 118(1-2), 7- humerus. Injury, 47, S20-S24. 13.

Wolff, J. 1986. The law of bone remodelling. Wanzl, M., Foehr, P., Schreiber, U., Burgkart, Translated by P. Maquet and R. Furlong. New R. H., \& Lenich, A. 2016. Biomechanical York, S pringer, 1(9), 8. 